\title{
Human islet cell implants in a nude rat model of diabetes survive better in omentum than in liver with a positive influence of beta cell number and purity
}

\author{
D. Jacobs-Tulleneers-Thevissen • K. Bartholomeus • \\ K. Suenens • I. Vermeulen • Z. Ling • K. H. Hellemans • \\ P. In't Veld • M. Pipeleers-Marichal • D. Pipeleers
}

Received: 31 October 2009 /Accepted: 11 February 2010/Published online: 16 April 2010

(C) Springer-Verlag 2010

\begin{abstract}
Aims/hypothesis Intraportal human islet cell grafts do not consistently and sustainably induce insulin-independency in type 1 diabetic patients. The reasons for losses in donor cells are difficult to assess in patients. This study in streptozotocin-diabetic nude rats examines whether outcome is better in an extra-hepatic site such as omentum. Methods Intraportal and omental implants of human islet cell grafts with the same beta cell number were followed for function and cellular composition over 5 weeks. Their outcome was also compared with that of rat islet cell grafts with similar beta cell numbers but higher purity.

Results While all intraportal recipients of rat islet cell grafts were normoglycaemic until post-transplant (PT) week 5, none was with human islet cell grafts; loss of human implants was associated with early infiltration of natural killer and CD45R-positive cells. Human islet cell implants in omentum achieved plasma human C-peptide positivity
\end{abstract}

D. Jacobs-Tulleneers-Thevissen and K. Bartholomeus contributed equally to this study.

Electronic supplementary material The online version of this article (doi:10.1007/s00125-010-1721-0) contains supplementary material, which is available to authorised users.

D. Jacobs-Tulleneers-Thevissen $\cdot$ K. Bartholomeus $\cdot$ K. Suenens $\cdot$

I. Vermeulen · Z. Ling $\cdot$ K. H. Hellemans $\cdot$ P. In't Veld •

M. Pipeleers-Marichal $\cdot$ D. Pipeleers $(\bowtie)$

Diabetes Research Center, Brussels Free University-VUB,

Laarbeeklaan 103,

1090 Brussels, Belgium

e-mail: Daniel.Pipeleers@vub.ac.be

D. Jacobs-Tulleneers-Thevissen $\cdot$ K. Bartholomeus $\cdot$ K. Suenens $\cdot$

I. Vermeulen $\cdot$ Z. Ling $\cdot$ K. H. Hellemans $\cdot$ P. In't Veld •

M. Pipeleers-Marichal $\cdot$ D. Pipeleers

JDRF Center for Beta Cell Therapy in Diabetes,

Brussels, Belgium and normoglycaemia in, respectively, nine of 13 and five of 13 recipients until PT week 5; failures were not associated with inflammatory infiltrates but with lower beta cell numbers and purity of the grafts. Observations in human and rat islet cell implants in the omentum suggest that a delayed revascularisation can interfere with their metabolic outcome. Irrespective of normalisation, human omental implants presented beta cell aggregates adjacent to alpha cells and duct cells.

Conclusions/interpretation In nude rats, human islet cell implants survive better in omentum than in liver, with positive influences of the number and purity of implanted beta cells. These observations can guide studies in patients.

Keywords Cell therapy · Endocrine pancreas · Insulin . Islets · Transplantation

$\begin{array}{ll}\text { Abbreviations } \\ \text { BW } & \text { Bodyweight } \\ \text { CK } & \text { Creatinine kinase } \\ \text { NK } & \text { Natural killer } \\ \text { PT } & \text { Post-transplant } \\ \text { TRFIA } & \text { Time-resolved fluorescence immunoassay }\end{array}$

\section{Introduction}

Intraportal islet cell implants can achieve insulinindependence in type 1 diabetic patients but most recipients lose this capacity during the first five post-transplant (PT) years [1]. Their functional deterioration is caused by an insufficient beta cell mass that already appears present before the return to an insulin-dependent state. One year after transplantation, insulin-independent patients exhibit 
insulin secretory capacity that is, on average, only $25 \%$ of that measured in matched non-diabetic controls [2]. It is unknown whether the donor beta cell number is marginal in the graft just before injection or whether it declines after implantation, either acutely as result of an inflammatory reaction [3] or chronically by deleterious influences of a metabolic, (auto)immune or pharmacological nature. The delay in metabolic normalisation, even following repetitive implants [1, 2], suggests that the beta cell mass is already marginal shortly after transplantation, and thus susceptible to becoming insufficient when subsequently exposed to negative local influences. It is therefore useful to identify factors that help increase the beta cell mass at the start of the PT period. These factors can be related to the donor tissue as well as to the implantation site. Their investigation is difficult to conduct in patients, not only because the implantation site is not accessible for histopathological analysis and sequential monitoring, but also because of the small number of cases in current protocols and of their multiple variables.

In view of these limitations we have chosen immunodeficient rodents as a model for investigating factors that influence the engraftment of human islet cell implants. For the present study we used immunodeficient Rowett nude rats [4] with streptozotocin-induced diabetes, which have already served for a short-term follow-up of human islet implants under the kidney capsule [5]. We were particularly interested in the influence of the composition of human beta cell grafts. In previous work with rat islet cell grafts transplanted into the liver we found that their endocrine purity favoured their survival and function, as both syngeneic and allogeneic implants [6-8]. We have not succeeded in preparing human islet cell grafts with the same endocrine purity as rat islet cell grafts, which raises the question whether this negatively influences their function as implants $[2,9]$. The main non-endocrine component consists of duct cells $[2,10]$ that might be considered as potential inducers and active participants in local inflammatory and immune reactions, given their expression of tissue factor [11], CD40 [12] and MHC-II antigens [13], and their production of cytokines and nitric oxide $[14,15]$. The duct cell contamination of human islet cell grafts could make them particularly vulnerable after injection into the portal vein, as this exposes the graft directly to blood- and liver-mediated reactions [3, 11, 16-18].

In the present study we compared survival and function of cultured human islet cell grafts that were implanted either intraportally or in the omentum, a non-intravascular site with portal drainage. The omentum has been previously used for transplantation of islets from rats, dogs and cynomologus monkeys in syngeneic and allogeneic combinations [19-24]. Cultured rat islet cell grafts with higher endocrine purity were examined in parallel.

\section{Methods}

Preparation and characterisation of rat and human islet cell grafts Throughout this manuscript the term 'graft' is used for the donor islet cell preparation before implantation, and 'implant' for the recipient tissue after injection. Rat islets were isolated from male Wistar rats (200-250 g; Elevage Janvier, Le Genest-Saint-Isle, France) using a modified collagenase method [25]. After handpicking, islets were cultured for 3 days in $10 \mathrm{mmol} / \mathrm{l}$ glucose in Ham's F10 medium (Lonza, Verviers, Belgium) supplemented with 2\% (vol./vol.) neonatal bovine serum, $0.5 \%$ (wt/vol.) BSA, $2 \mathrm{mmol} / \mathrm{l}$ glutamine and antibiotics (Sigma-Aldrich, Steinheim, Germany). On the day of transplantation, islets were handpicked again and samples taken to determine their cellular composition and insulin content [25] (Table 1).

Human islet cell fractions were obtained from the Beta Cell Bank in Brussels, which processes donor organs for clinical islet transplantation [26]. The organs are recovered at European hospitals affiliated with the Eurotransplant Foundation (Leiden, the Netherlands). Fractions that cannot be used for clinical transplantation are made available to research projects when these are relevant for cell therapy in diabetes and approved by Eurotransplant and by scientific and ethics review committees. The present study used nine preparations with a composition and viability in the range of the criteria in current clinical protocols [2]. They were obtained from donors aged 13-59 years and had been cultured for 4-19 days in Ham's F10 with $7.5 \mathrm{mmol} / 1$ glucose, $2 \mathrm{mmol} /$ 1 glutamine, antibiotics and $0.5 \%$ (wt/vol.) human albumin [26]. On the day of transplantation, samples were taken for cellular composition and insulin content [10] (Table 1).

Transplantation in nude rats Male Rowett nude rats (Hsd: RH-Foxn $1^{r n u / r n u}$, age 7-10 weeks; Harlan, Horst, the Netherlands) were housed and handled under supervision of a staff veterinarian of our university. The animal ethics committee of Brussels Free University-VUB approved the protocol and procedures. The rats had free access to water and standard laboratory animal food. Diabetes was induced by $60 \mathrm{mg} / \mathrm{kg}$ streptozotocin IV (Sigma-Aldrich). Animals in a stable diabetic state ( $2 \mathrm{~h}$ fasting glycaemia $>20 \mathrm{mmol} / \mathrm{l}$ ), received a rat islet cell graft 1 week later. Since the availability of human islet cell preparations could not be planned, their recipients had a variable duration of pretransplant diabetes (1-3 weeks). To avoid their death during this period they received an insulin implant (Linplant; LinShin, Scarborough, Canada) together with $10 \%$ (wt/vol.) sucrose drinking water [27]; the insulin implant was inserted 2-10 days prior to transplantation, and maintained during the first 2 weeks after transplantation in order to avoid sustained hyperglycaemia during engraftment. On PT 
Table 1 Characteristics of rat and human islet cell grafts

Data are means \pm SEM ${ }^{*} p<0.05 ; * * p<0.01$; $* * * p<0.001$

\begin{tabular}{lll}
\hline Characteristic & Rat islet cell grafts $(n=10)$ & Human islet cell grafts $(n=9)$ \\
\hline $\begin{array}{l}\text { Pretreatment (days in culture) } \\
\text { Beta cells }\end{array}$ & 3 & $4-19$ \\
Beta cell number $\left(\times 10^{6} / \mathrm{kg} \mathrm{BW}\right)$ & & \\
Mean & $7 \pm 0.4$ & $10 \pm 1^{*}$ \\
Range & $5-10$ & $5-25$ \\
Purity $(\%$ insulin-positive cells) & $68 \pm 2$ & $35 \pm 4^{* * *}$ \\
Insulin content $\left(\mu \mathrm{g} / 10^{6}\right.$ beta cells) & $13 \pm 2$ & $22 \pm 4$ \\
Other cell types & & \\
Glucagon-positive cells $(\%)$ & $15 \pm 1$ & $11 \pm 3$ \\
Non-granulated cells $(\%)$ & $12 \pm 1$ & $35 \pm 4^{* * *}$ \\
Dead cells $(\%)$ & $5 \pm 1$ & $24 \pm 5^{* *}$
\end{tabular}

day 14, insulin implants were removed together with surrounding tissue under isoflurane anaesthesia.

Transplantation was performed under general anaesthesia (ketamine and xylazine). For implantation in the liver, the cultured islet cell preparation was injected as a suspension into the portal vein; for omental implants, it was embedded in a fibrin matrix (Tissucol; Baxter, Vienna, Austria) and inserted between the omental sheets under stereomicroscopic control.

Monitoring survival and function of beta cell implants For human beta cell grafts, survival of implanted beta cells was detected and followed through the presence of human C-peptide in plasma. Human C-peptide was measured by a time-resolved fluorescence immunoassay (TRFIA) using a modification of a commercial TRFIA kit (PerkinElmer, Zaventem, Belgium) [28] to increase sensitivity. Duplicate $25 \mu \mathrm{l}$ plasma samples were pipetted into a microtitre plate (PerkinElmer) coated with anti-human C-peptide monoclonal antibody (mAb) PEP-001 (Dako, Glostrup, Denmark). After adding $100 \mu \mathrm{l}$ of the first incubation buffer $(0.04 \mathrm{~mol} / \mathrm{l}$ phosphate $\mathrm{pH} 7.4,60 \mathrm{~g} / 1 \mathrm{NaCl}, 30 \mathrm{~g} / \mathrm{l} \mathrm{BSA}, 1 \mathrm{~g} / 1$ bovine gamma globulin, $1 \mathrm{ml} / 1$ TWEEN 20 and $0.5 \mathrm{~g} / 1 \mathrm{NaN}_{3}$ ) the plate was incubated for $2 \mathrm{~h}$ at room temperature under gentle shaking. The wells were washed (wash solution, PerkinElmer), incubated for $2 \mathrm{~h}$ with europium-labelled anti-C-peptide mAb CPT3-F11 (30 $\mu \mathrm{g} / \mathrm{ml}$; Dako) in 'TRFIA assay buffer' (PerkinElmer), washed again, filled with $140 \mu \mathrm{l}$ 'enhancement solution' (PerkinElmer), shaken for $5 \mathrm{~min}$, and analysed for their time-resolved europium fluorescence in a Victor ${ }^{2}$ TRF-counter (PerkinElmer). Least squares linear regression analysis was performed to obtain results in nmol/l. The lower level of human C-peptide sensitivity in rat plasma was $0.02 \mathrm{nmol} / \mathrm{l}$. In none of 120 pre-transplant samples was any human C-peptide measured. Recovery of human C-peptide added to rat plasma $(0.03$, $0.05,0.1$ and $0.2 \mathrm{nmol} / \mathrm{l}$ ) was $>95 \%$; a concentration of $0.03 \mathrm{nmol} / \mathrm{l}$ was set as the minimal level for defining the presence of surviving human beta cells. Rat C-peptide could not be used as a survival index for implanted rat beta cells as it will also detect $\mathrm{C}$-peptide released by the diabetic pancreas. Plasma rat C-peptide levels were measured to compare transplant groups and normal and diabetic controls (C-peptide kit from Linco, St Charles, MO, USA). Blood samples for C-peptide assays were collected in Na-EDTA $(1.6 \mathrm{mg} / \mathrm{ml}$ blood) and aprotinin (600 kallikrein inactivator units/ml blood; Trasylol, Bayer Healthcare, Leverkusen, Germany) and kept at $-20^{\circ} \mathrm{C}$ until the assay.

The function of beta cell implants was assessed through the normalisation of morning glycaemia following $2 \mathrm{~h}$ of fasting. Tail vein blood was analysed (Glucocard Memory PC; A. Menarini Diagnostics, Florence, Italy) daily during PT week 1 and weekly thereafter. Possible interference by beta cell function in the pancreas was assessed by measuring the insulin content in the pancreas of transplanted rats; in none of the animals were values measured above $10 \%$ of the content in normal controls.

Histopathology of implants On PT day 4 and weeks 1, 2, 3, 5 or 10, animals were killed for graft harvesting. Tissue was fixed in 4\% (wt/vol.) neutral phosphate-buffered formalin and embedded in paraffin. Sections $(4 \mu \mathrm{m})$ were made for haematoxylin-eosin-saffron staining and for overnight incubation $\left(4^{\circ} \mathrm{C}\right)$ with rabbit anti-glucagon $(1: 5,000)$ and guinea pig anti-insulin $(1: 10,000)$ (both a gift from $\mathrm{C}$. Van Schravendijk at our Center) and with mouse anti-creatinine kinase (CK) 19 (1:20, trypsin antigen retrieval; Dako).

When haematoxylin-eosin-saffron staining showed infiltrating cells, sections were also incubated with mouse antibodies against a natural killer (NK) cell marker (ANK-61) (1:300; Santa Cruz Biotechnology, Santa Cruz, CA, USA), $\alpha \beta$-T cell receptor $(1: 20$, microwave antigen retrieval; BD Biosciences, Erembodegem, Belgium) and CD45R (1:20; BD Biosciences). The antibody-treated sections were washed in PBS ( $\mathrm{pH} 7.4$ ), and then incubated with biotinlinked anti-rabbit IgG (1:300; Amersham International, 
Amersham, UK), anti-guinea pig $\operatorname{IgG}(1: 1,000$; Vector Laboratories, Burlingame, CA, USA) or anti-mouse IgG (1:300; Amersham International) for $30 \mathrm{~min}$ at room temperature. Detection was performed with the Vectastain Elite ABC kit (PK-6100; Vector Laboratories). The peroxidase reaction was developed with a DAB Development Kit (Dako). Digital images were acquired using an Axiophot microscope (Carl Zeiss, Jena, Germany) fitted with an Axiocam MRc5 camera (Carl Zeiss), and processed using AxioVision software (Carl Zeiss).

Measuring the endothelial cell surface area associated with an insulin-positive area, and calculating the ratio of both areas, assessed the vascularisation of omental beta cell implants. Endothelial cells were stained with Bandeiraea simplicifolia lectin, a marker that has been previously used by Mattson et al. to study the vascularisation of endogenous and transplanted islets [29] (biotin-labelled; 1:500; neuraminidase antigen retrieval, $3 \mathrm{~h}, 37^{\circ} \mathrm{C}$; Vector Laboratories). For each implant, two sections were stained with the endothelial marker and with the insulin antibody $(1: 1,000)$ (overnight incubation at $4^{\circ} \mathrm{C}$ ). After a wash in PBS, they were incubated ( $1 \mathrm{~h}$, room temperature) with Alexa Fluor 488-conjugated anti-guinea pig (1:500; Invitrogen, Carlsbad, CA, USA) and with Alexa Fluor 647-conjugated streptavidin (1:500; Invitrogen). Nuclei were subsequently stained with DAPI (Sigma-Aldrich) in fluorescent mounting medium (Dako). Sections were photographed on the Pathway 435 (BD Biosciences, Rockville, MD, USA) and images analysed with IP Lab 4.0 software (BD Biosciences).

Statistical analysis Results are expressed as means \pm SEM. Statistical analysis was carried out using Prism4 for Macintosh (GraphPad Software, San Diego, CA, USA). Differences between two experimental groups were calculated with an unpaired two-tailed $t$ test. Comparison among three groups was performed with one-way ANOVA using Tukey's post hoc test. Statistical significance was assumed at $p<0.05$.

\section{Results}

Correction of diabetes in nude rat recipients of intraportal or omental grafts of cultured rat islet cells Intraportal transplantation of cultured rat islet cell grafts containing $5-10 \times 10^{6}$ beta cells per $\mathrm{kg}$ bodyweight (BW) significantly reduced $2 \mathrm{~h}$ fasting blood glucose levels from PT day 2 onwards and reached normal values for seven of nine animals on PT week 1 and for nine of nine on PT week 3 (Table 2, Fig. 1). Liver sections showed endocrine aggregates containing insulin- and glucagon-positive cells and devoid of infiltrating cells (Fig. 2).

In the series receiving omental implants of similar grafts, ten of 18 animals were normoglycaemic at PT week 1, and
Table 2 Correction of diabetes by rat islet cell implants in liver or omentum

\begin{tabular}{lcc}
\hline Glycaemia at PT week 1 & \multicolumn{2}{c}{ Glycaemia $<8.5 \mathrm{mmol} / 1$} \\
\cline { 2 - 3 } & PT week 3 & PT week 5 \\
\hline Liver implant $(n=9)$ & & $7 / 7$ \\
$<8.5 \mathrm{mmol} / \mathrm{l}(n=7)$ & $7 / 7$ & $2 / 2$ \\
$>8.5 \mathrm{mmol} / \mathrm{l}(n=2)$ & $2 / 2$ & \\
Omentum implant $(n=18)$ & & $10 / 10$ \\
$<8.5 \mathrm{mmol} / \mathrm{l}(n=10)$ & $10 / 10$ & $6 / 8$ \\
$>8.5 \mathrm{mmol} / \mathrm{l}(n=8)$ & $4 / 8$ & \\
\hline
\end{tabular}

six others normalised over the following 4 weeks (Table 2). The two recipients that did not normalise presented plasma C-peptide levels that were higher than those in diabetic controls $(0.19 \pm 0.03 \mathrm{nmol} / 1$ vs $0.09 \pm 0.01 \mathrm{nmol} / 1, p<0.001)$ but lower than in normalised recipients $(0.59 \pm 0.02 \mathrm{nmol} / \mathrm{l}$, $p<0.001)$. Omental implants of beta cell grafts can thus correct diabetes in nude rats but the normalisation proceeds more slowly than in intraportal implants (Fig. 1) and does not occur in all recipients (Table 2). In both normalised and non-normalised animals, omental implants contained endocrine aggregates of insulin- and glucagon-positive cells without lymphocytic or inflammatory infiltrations (Fig. 2). Their revascularisation was evaluated by measuring at three different time points the size of the endothelial cell surface area that was associated with the insulin-positive area (see Methods, three animals for each time point). A marked increase in blood vessel density was seen between PT day 4 $(2.0 \pm 1.1 \%)$ and PT week $2(9.3 \pm 0.5 \%, p<0.01)$, but not thereafter (PT week 5: $9.0 \pm 0.9 \%$ ).

Failure of human islet cell grafts following intraportal transplantation in diabetic nude rats A series of 13 nude rats were intraportally transplanted with a human islet cell graft containing $5-25 \times 10^{6}$ beta cells per $\mathrm{kg}$ BW. Four animals died within $4 \mathrm{~h}$ of transplantation. Of the animals that survived the intervention day, seven of nine were plasma human C-peptide-positive on PT week 1, but only two remained so until PT week 5, and only one achieved a normal $2 \mathrm{~h}$ fasting glycaemia shortly after removal of the insulin implant but not as long as PT week 5 (Table 3). Of the two of nine animals that were human C-peptidenegative at PT week 1, neither became C-peptide-positive or normoglycaemic at a later time point. These data and their time course (Fig. 1) are indicative of a massive loss of donor beta cells during the first 3 PT weeks.

Shortly after intraportal injection, insulin-containing aggregates were readily seen in liver sections; they were associated with glucagon-positive cells as well as with CK19-positive cells and often embedded in an organised 
a

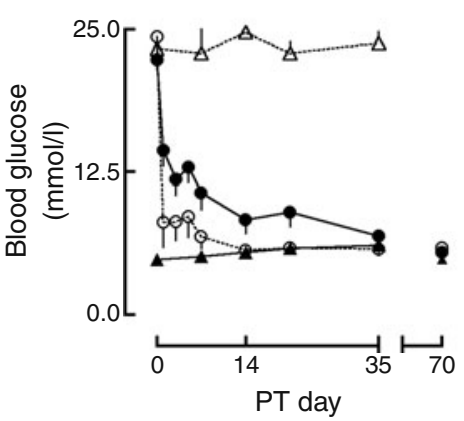

b

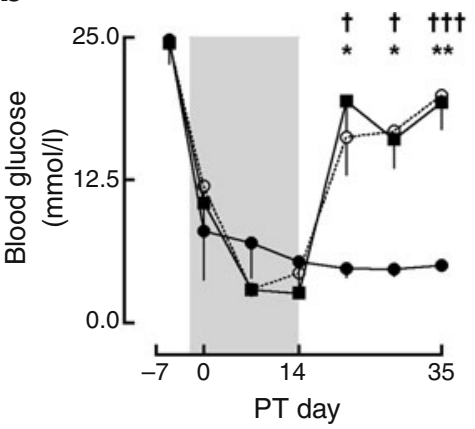

C

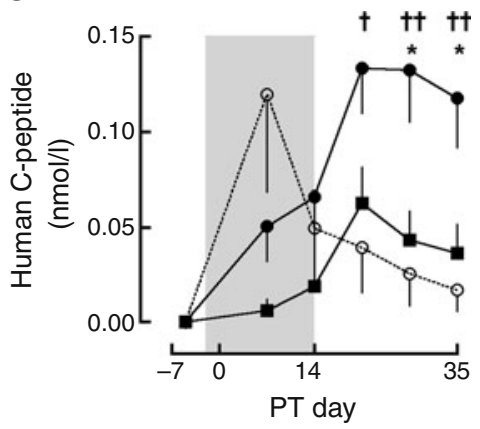

Fig. 1 Glycaemia ( $2 \mathrm{~h}$ fasting) (a, b) and human plasma C-peptide levels (c) as means \pm SEM. a Longitudinal follow-up of streptozotocin-diabetic nude rats receiving a rat beta cell graft in liver (open circles; $n=9$ ) or omentum (black circles; $n=18$ ). Diabetic (open triangles; $n=8$ ) and normal (black triangles; $n=6$ ) controls are followed in parallel. b, $\mathbf{c}$ Recipients of a human islet cell graft carry an insulin implant during the first 2 weeks after transplantation (grey zone). Omentum-normalised (black circles; $n=5$ ) recipients of a human beta cell graft are compared with omentum-not-normalised (black squares; $n=8$ ) and liver (open circles; $n=9$ ) recipients (one-way ANOVA with Tukey's post hoc test: ${ }^{*} p<0.05 ;{ }^{*} p<0.01$ vs omentumnot-normalised and ${ }^{\dagger} p<0.05 ;{ }^{\dagger \dagger} p<0.01 ;{ }^{\dagger \dagger} p<0.001$ vs liver)

became and remained normoglycaemic after removal of the insulin implant (Table 3). Of the eight of 13 animals that were human C-peptide-negative at PT week 1, six became positive at a later time point but only one induced a normal $2 \mathrm{~h}$ fasting glycaemia until PT week 5 (Table 3).

The five omental recipients with normalised $2 \mathrm{~h}$ fasting glycaemia at PT week 5 had consistently higher PT plasma human C-peptide levels than the eight omental recipients without normalisation (Fig. 1). Compared with the group of intraportal recipients, the plasma human C-peptide levels of both omental subgroups were lower at PT week 1 but not after removal of the insulin implant (Fig. 1).

All examined omental implants presented insulinpositive cell aggregates associated with glucagon-positive and CK19-positive cells. The majority of CK19-positive cells were lining cyst-like structures. A mild lymphocytic remained positive until PT week 5, and four of them

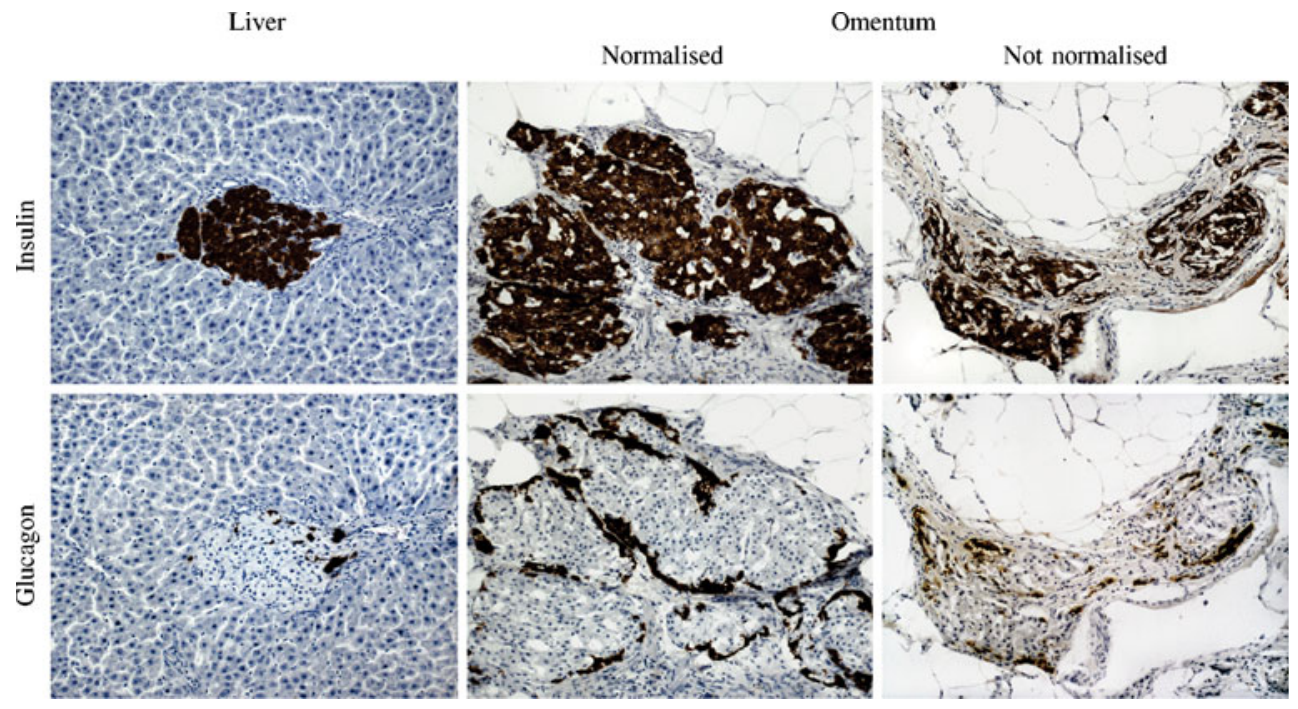

Fig. 2 Presence of insulin- and glucagon-positive cells in consecutive sections of rat islet cell implants in liver (normalised glycaemia) or omentum (normalised glycaemia or not normalised glycaemia). Implants were removed on PT day 70 
Table 3 Survival and function of human islet cell implants in liver or in omentum

\begin{tabular}{lccccc}
\hline Plasma human C-peptide at PT week 1 & \multicolumn{2}{c}{ Plasma human C-peptide-positive } & & \multicolumn{2}{c}{ Glycaemia $<8.5 \mathrm{mmol} / 1$} \\
\cline { 2 - 3 } \cline { 5 - 6 } & PT week 3 & PT week 5 & & PT week 3 & PT week 5 \\
\hline Liver implant $(n=9)$ & $3 / 7$ & $2 / 7$ & & $1 / 7$ & $0 / 7$ \\
Positive $(n=7)$ & $0 / 2$ & $0 / 2$ & & $0 / 2$ & $0 / 2$ \\
Negative $(n=2)$ & & & & $4 / 5$ \\
Omentum implant $(n=13)$ & $5 / 5$ & $5 / 5$ & & $4 / 5$ \\
Positive $(n=5)$ & $6 / 8$ & $4 / 8$ & & $2 / 8$ & $1 / 8$ \\
Negative $(n=8)$ & & & &
\end{tabular}

infiltration was observed; it consisted predominantly of cells that stained positive for ANK-61 (Fig. 3). In both transplanted and non-transplanted nude rats, CD45Rpositive cells were scattered throughout the omentum with sometimes focal accumulations (Fig. 3). They belong to the omental lymphocyte population with a possible role in adaptive immunity [30]. The omental implants in recipients that did not normalise presented the same donor and recipient cell types but contained more fibrosis; in one case the presence of giant cells around birefringent extracellular material was indicative of a foreign body reaction, possibly to an amorphous contaminant in the graft.

Influence of composition of human islet cell grafts on their survival and function in diabetic nude rats Since four recipients of an intraportal implant died shortly after injection, the 5 week outcome was studied in nine animals with an intraportal implant and 13 with an omentum implant. This drop out did not cause a difference in average composition of the grafts used in the two series of surviving animals (Electronic supplementary material [ESM] Table 1). Since none of the nine intraportal survivors had a glycaemia correction at PT week 5, it can be concluded that failure occurred irrespectively of the source of the donor preparation (the nine grafts were prepared from five different pancreatic isolates). On the other hand, five of 13 omental implants exhibited a glycaemic correction at PT week 5. Their grafts differed in cellular composition from those used in the subgroup of eight omental recipients without glycaemic correction at PT week 5 (Table 4); they contained a higher number of beta cells per $\mathrm{kg} \mathrm{BW}(p<0.01)$ at higher purity and no differences were seen in the respective percentages of glucagon-positive cells, nongranulated cells or dead cells. Since omental recipients with plasma human C-peptide positivity at PT week 1 exhibited a better outcome at PT week 5 than C-peptidenegatives at PT week 1, we also compared the composition of grafts used for these two subgroups (Table 5). This analysis showed that the C-peptide-positive subgroup had received grafts with, on average, a higher purity of beta cells $(40 \pm 5 \%$ vs $30 \pm 2 \%, p<0.05)$ and of endocrine cells (beta plus alpha cells: $53 \pm 6 \%$ vs $39 \pm 3 \%, p<0.05$ ). The average number of implanted beta cells and per cent living cells was also higher, but this was not statistically significant (Table 5).

\section{Discussion}

Intraportal transplantation of syngeneic or allogeneic rat islets results in long-term correction of diabetes, but this is not the case in type 1 diabetic patients receiving allogeneic human islet cell grafts. Several donor and recipient factors can account for this difference, some of which can be investigated in animal models. This study used diabetic nude rats to examine whether human islet cell implants in the omentum have a better outcome than in the portal bed. It is based on the rationale that properties of currently used human islet cell preparations may interfere with their engraftment and survival in the intraportal site. Furthermore, the omental site offers the advantage that the implant can be resected for a representative quantitative and qualitative analysis.

In the first part, the selected animal model was validated by demonstrating that both intraportal and omental implants of cultured rat islet cell grafts can correct streptozotocininduced diabetes. In both sites, normalisation of $2 \mathrm{~h}$ fasting glycaemia was achieved and maintained by grafts containing $5-10 \times 10^{6}$ beta cells per $\mathrm{kg} \mathrm{BW}$ and over $80 \%$ endocrine purity, which is consistent with previous data in streptozotocin-diabetic immunocompetent rats receiving an intraportal injection of cultured syngeneic or allogeneic islet cells [6-8]. Our data confirm that islet cell implants in the omentum can correct experimental diabetes [19, 21, 23, 24]. However, glycaemic normalisation in the omentum took on average 1 week longer than in the portal bed (present data in nude rats) or the renal subcapsular space [23]. We also noted $10 \%$ failures of omental grafts, but not of intraportal grafts. These differences were not because of differences in beta cell number or due to an inflammatory or immune-mediated reactivity. They can be attributed to the delayed revascularisation of the implants in the 


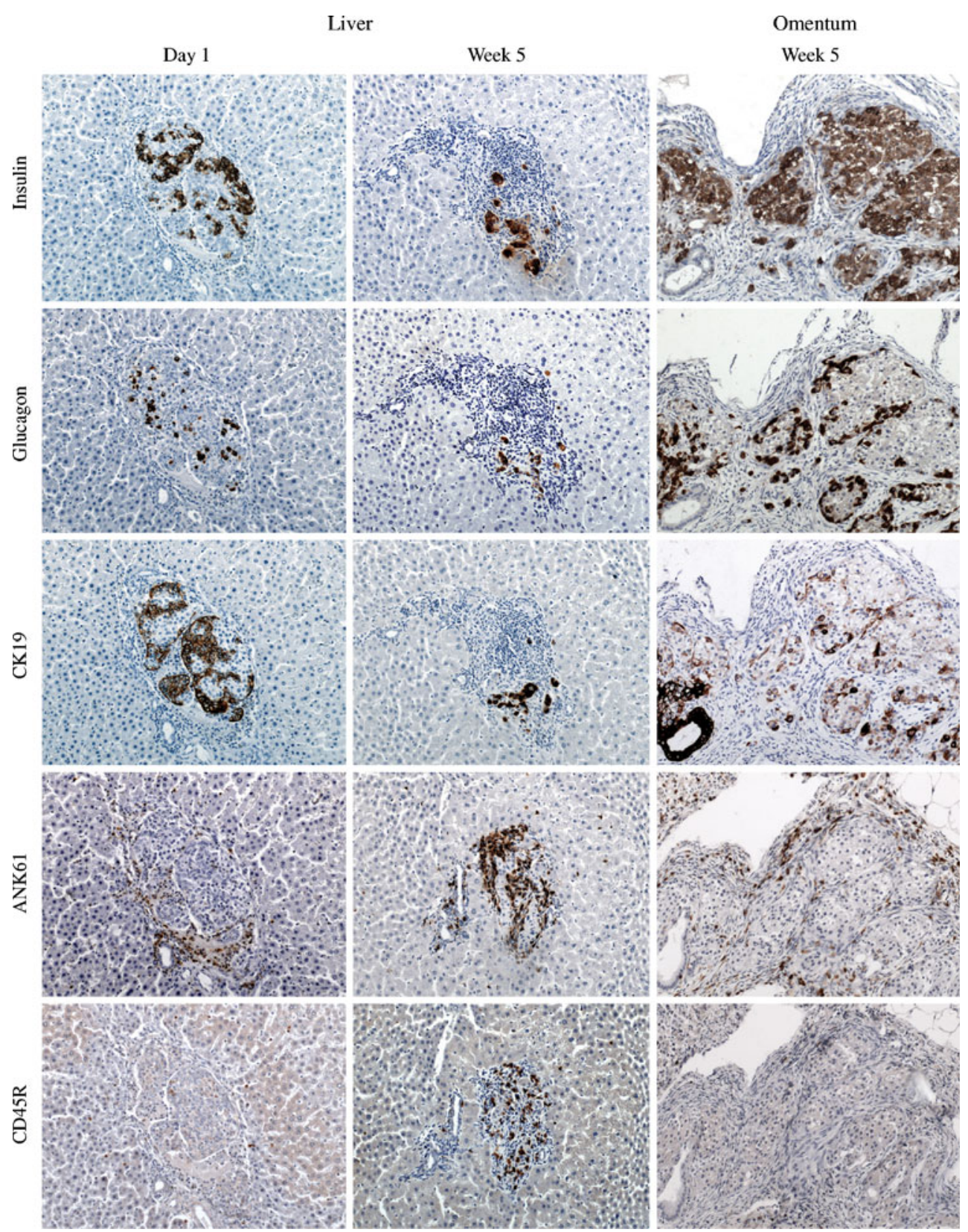

Fig. 3 Composition of human islet cell implants in liver (PT day 1 and week 5) or in omentum (PT week 5). Consecutive sections were stained for insulin, glucagon, CK19 and NK (ANK-61) and CD45R markers. The composition of the liver implant at PT week 5 is representative of human C-peptide-positive animals at PT week 3 or 5. The composition of the omental implant at PT week 5 is representative of normalised and not normalised recipients at PT week 3 or 5 omentum. Intraportally transplanted rat islets are assumed to have rapid access to blood flow, as can be judged from their metabolic normalisation within the first PT days. This is unlikely for omental implants, which exhibit a delay in their endocrine function. Their endothelial cell density was low at PT day 4, but increased fourfold within the next 10 days, up to levels that are maintained through to the end of the study. It is conceivable that a marginal nutrient and oxygen supply during the first PT days can be responsible for early beta cell losses in omental implants, and thus explain the two of 18 metabolic failures in implants that maintained beta cell aggregates without signs of inflammatory reactivity.

While all intraportal recipients of cultured rat islet cell grafts exhibited a normalised glycaemia at PT week 5 , none did so with cultured human islet cells that contained a comparable number of beta cells per kg BW. Four of 13 recipients died shortly after transplantation and the others lost the implanted cells over the first 3 weeks. Grafts were surrounded by a blood coagulate on the day of transplan- 
Table 4 Composition of grafts with or without normalisation of glycaemia 5 weeks after implantation in omentum

\begin{tabular}{lcc}
\hline Composition of human islet cell graft & \multicolumn{2}{l}{$\begin{array}{l}\text { 2h fasting glycaemia } \\
<8.5 \mathrm{mmol} / \mathrm{l} \text { at PT week 5 }\end{array}$} \\
\cline { 2 - 3 } & Yes $(n=5)$ & No $(n=8)$ \\
\hline Beta cells & & \\
Beta cell number ( $\left.\times 10^{6} / \mathrm{kg} \mathrm{BW}\right)$ & $16 \pm 3$ & $7 \pm 1^{* *}$ \\
Purity (\% insulin-positive cells) & $39 \pm 5$ & $31 \pm 2$ \\
Insulin content ( $\mu \mathrm{g} / 10^{6}$ beta cells) & $26 \pm 2$ & $20 \pm 5$ \\
Other cell types & & \\
Glucagon-positive cells (\%) & $13 \pm 4$ & $9 \pm 2$ \\
Non-granulated cells (\%) & $31 \pm 3$ & $37 \pm 4$ \\
Dead cells $(\%)$ & $20 \pm 3$ & $24 \pm 6$ \\
\hline
\end{tabular}

Data are means \pm SEM

$* * p<0.01$

tation and became progressively more infiltrated by cells positive for B cell or NK cell markers, a process that was not noticed with rat islet cell grafts. This process bears analogy with that causing failure of porcine islet cell grafts in the portal vein of nude rats [31] or of pigs [3]. It is not known to what extent it is initiated by a residual xenoreactivity in the nude rat recipients [32], by tissue factor expressed by the donor islet cells [33] and/or by its lower endocrine purity. As in the study of Moberg et al. [33] our human islet cell preparations also express tissue factor that can induce blood coagulation in vitro [11]; however, we found it predominantly in the duct cells that are known to be much more abundant in human than in rat islet cell preparations $[9,10]$. Human duct cells are also a potent source of cytokines and of cytokine-mediated reactions [14, 15], which adds support to making them a suspect for interfering with the outcome of human islet cell grafts [9]. Direct evidence for such influence is, however, lacking, since no comparative data exist on the outcome of the presently used human islet cell grafts with $50 \%$ endocrine purity and that of grafts with $>90 \%$ purity, as in previous studies with rat beta cell grafts [25]. In fact, we have so far not been able to prepare human islet cell grafts at this purity because of the shortage of donor tissue and the low recovery of FACS-purified human endocrine islet cells.

A markedly better outcome was observed when human islet cell grafts were implanted in the omentum. None of the recipients died; nine of 13 maintained surviving beta cells until PT week 5 (vs two of nine intraportal implants), of which five exhibited glycaemic normalisation (vs none of nine intraportal implants). The normalised state at PT week 5 correlated with a higher number of beta cells in the graft $\left(16 \times 10^{6} \pm 3 \times 10^{6}\right.$ beta cells per kg BW vs $7 \times 10^{6} \pm$ $1 \times 10^{6}$ in omental recipients without normalisation). This confirms the usefulness of quantifying beta cell numbers in cultured human islet cell grafts for standardisation and prediction of metabolic outcome [2]. As for rat islet cell implants, the normalisation for omental human implants was correlated with graft function at PT week 1; four of five human C-peptide-positives at PT week 1 were normoglycaemic at PT week 5 vs only one of eight C-peptidenegatives. Retrospective analysis showed that the PT week 1 C-peptide-positive subgroup had received grafts with a higher purity in beta cells $(40 \pm 5 \%$ vs $30 \pm 2 \%, p<0.05)$ and in endocrine cells $(53 \pm 6 \%$ vs $39 \pm 3 \%, p<0.05)$. This purity is still much lower than that in the present and in our previous studies [6-8] with rat islet cell grafts, but its better outcome vs less pure grafts supports the view that higher endocrine purities of human islet cell grafts can help achieve a better outcome.

The omentum seems a better site to test further this hypothesis than the liver, as it circumvents acute losses in donor cells that might occur following intraportal injection. Its portal drainage might represent a physiological advantage over the renal subcapsular space. In the latter site, human islet implants were also found to correct diabetes in nude rats (in five of seven recipients until PT week 3); the
Table 5 Composition of grafts with or without plasma C-peptide positivity 1 week after implantation in omentum

\begin{tabular}{lll}
\hline Composition of human islet cell graft & \multicolumn{2}{l}{ Plasma human C-peptide at PT week 1} \\
\cline { 2 - 3 } & Positive $(n=5)$ & Negative $(n=8)$ \\
\hline Pretreatment (days in culture) & $4-19$ & $5-14$ \\
Beta cells & & \\
Beta cell number $\left(\times 10^{6} / \mathrm{kg} \mathrm{BW}\right)$ & $13 \pm 3$ & $9 \pm 2$ \\
Purity (\% insulin-positive cells) & $40 \pm 5$ & $30 \pm 2 *$ \\
Insulin content $\left(\mu \mathrm{g} / 10^{6}\right.$ beta cells) & $26 \pm 2$ & $20 \pm 5$ \\
Other cell types & & \\
Glucagon-positive cells $(\%)$ & $13 \pm 4$ & $9 \pm 2$ \\
Non-granulated cells $(\%)$ & $34 \pm 4$ & $37 \pm 4$ \\
Dead cells $(\%)$ & $19 \pm 4$ & $24 \pm 6$ \\
\hline
\end{tabular}

Data are means \pm SEM $* p<0.05$ 
two that failed presented a monocytic infiltration [5]. We did observe a mild infiltration of NK marker-positive cells in all omental implants, irrespective of whether they had normalised hyperglycaemia. All implants mainly consisted of insulin-positive aggregates associated with glucagonpositive cells and of cystic structures that are predominantly composed of CK19-positive cells with dispersed endocrine cells. It would be interesting to determine whether elimination of duct cells from the graft results in implants without infiltrates. The endocrine purity of the islet cell grafts may influence the revascularisation process [34], which can vary with the selected implant site $[35,36]$ and donor tissue. In view of the revascularisation kinetics in omental rat cell implants, this site should allow investigation of whether this is the case. Our observations with human islet cell grafts are indicative of such influences, given the observed correlations between PT week 1 Cpeptide positivity, endocrine purity of the graft and subsequent metabolic outcome.

Human islet cell grafts that corrected diabetes in the nude rats contained 2.3-fold more beta cells than the rat beta cell grafts $\left(16 \times 10^{6} \pm 3 \times 10^{6}\right.$ per kg BW vs $7 \times 10^{6} \pm$ $0.4 \times 10^{6}$ rat beta cells per kg BW). Furthermore, at doses in this range, human beta cell grafts never corrected hyperglycaemia within the first week (preliminary observations), which led us to maintain the insulin implant until PT day 14. Several reasons can explain this need for higher numbers of human beta cells, such as a lower biological activity of human insulin in rats and a lower sensitivity of human beta cells to growth/surviving factors from the rat recipient, a higher per cent of damaged or dysfunctional beta cells when these are isolated from cold-preserved donor organs and cultured for longer periods, and the presence of higher percentages of nonendocrine cells and/or a residual xenoreactivity. While a number of these reasons reflect the limitations of nude rats as a model for assessing influences on the functional beta cell mass of human islet cell implants, the observed correlations between graft composition and metabolic outcome indicates its usefulness for addressing clinically relevant questions that can so far not be examined in patients.

Acknowledgements The authors thank S. Darwich and S. Devos for their commitment in conducting the animal experiments, N. Buelens and S. D'Haese for their expert preparation of tissue sections, M. Chintinne and G. Stangé for their expertise with image analysis, and N. Van Slycke and S. Uyttenhove for excellent administrative support. They are grateful to the Beta Cell Bank and the Eurotransplant Foundation for providing valuable human islet cell preparations. This study was supported by grants from the Juvenile Diabetes Research Foundation (Center Grant 4-2005-1327) and the Research Foundation Flanders (FWO; G0653.06). D. Jacobs-Tulleneers-Thevissen is a PhD fellow of FWO and K. Bartholomeus has been a fellow of the IWT.

Duality of interest The authors declare that there is no duality of interest associated with this manuscript.

\section{References}

1. Ryan EA, Paty BW, Senior PA et al (2005) Five-year follow-up after clinical islet transplantation. Diabetes 54:2060-2069

2. Keymeulen B, Gillard P, Mathieu C et al (2006) Correlation between beta cell mass and glycemic control in type 1 diabetic recipients of islet cell graft. Proc Natl Acad Sci U S A 103:17444-17449

3. Bennet W, Sundberg B, Groth CG et al (1999) Incompatibility between human blood and isolated islets of Langerhans: a finding with implications for clinical intraportal islet transplantation? Diabetes 48:1907-1914

4. Schuurman HJ, Hougen HP, Loveren HV (1992) The rnu (Rowett nude) and $r n u^{\mathrm{N}}$ (nznu, New Zealand nude) rat: an update. ILAR Journal V34. Available from http://dels.nas.edu/ilar_n/ilarjournal/ $\begin{array}{llllll}34 & 1 & 2 / 34 & 1 & 2 \text { rnuRat.shtml }\end{array}$

5. Lake SP, Chamberlain J, Bassett PD et al (1989) Successful reversal of diabetes in nude rats by transplantation of isolated adult human islets of Langerhans. Diabetes 38:244-248

6. Keymeulen B, Anselmo J, Pipeleers D (1997) Length of metabolic normalization after rat islet cell transplantation depends on endocrine cell composition of graft and on donor age. Diabetologia 40:1152-1158

7. Keymeulen B, Korbutt G, De Paepe M, Gorus F, Klöppel G, Pipeleers DG (1996) Long-term metabolic control by rat islet grafts depends on the composition of the implant. Diabetes 45: 1814-1821

8. Pipeleers DG, Pipeleers-Marichal M, Vanbrabandt B, Duys S (1991) Transplantation of purified islet cells in diabetic rats. II. Immunogenicity of allografted islet beta-cells. Diabetes 40:920 930

9. Pipeleers D, Keymeulen B, Chatenoud L et al (2002) A view on beta cell transplantation in diabetes. Ann N Y Acad Sci 958:69-76

10. Keymeulen B, Ling Z, Gorus FK et al (1998) Implantation of standardized beta-cell grafts in a liver segment of IDDM patients: graft and recipients characteristics in two cases of insulinindependence under maintenance immunosuppression for prior kidney graft. Diabetologia 41:452-459

11. Beuneu C, Vosters O, Movahedi B et al (2004) Human pancreatic duct cells exert tissue factor-dependent procoagulant activity: relevance to islet transplantation. Diabetes 53:1407-1411

12. Vosters O, Beuneu C, Nagy N et al (2004) CD40 expression on human pancreatic duct cells: role in nuclear factor-kappa B activation and production of pro-inflammatory cytokines. Diabetologia 47:660-668

13. Pavlovic D, van de Winkel M, van der Auwera B et al (1997) Effect of interferon-gamma and glucose on major histocompatibility complex class I and class II expression by pancreatic betaand non-beta-cells. J Clin Endocrinol Metab 82:2329-2336

14. Pavlovic D, Chen MC, Bouwens L, Eizirik DL, Pipeleers D (1999) Contribution of ductal cells to cytokine responses by human pancreatic islets. Diabetes 48:29-33

15. Movahedi B, Van de Casteele M, Caluwé N et al (2004) Human pancreatic duct cells can produce tumour necrosis factor-alpha that damages neighbouring beta cells and activates dendritic cells. Diabetologia 47:998-1008

16. Lau J, Mattsson G, Carlsson C et al (2007) Implantation sitedependent dysfunction of transplanted pancreatic islets. Diabetes $56: 1544-1550$

17. Lee Y, Ravazzola M, Park BH, Bashmakov YK, Orci L, Unger RH (2007) Metabolic mechanisms of failure of intraportally transplanted pancreatic beta-cells in rats: role of lipotoxicity and prevention by leptin. Diabetes 56:2295-2301

18. Desai N, Goss J, Deng S et al (2003) Elevated portal vein drug levels of sirolimus and tacrolimus in islet transplant recipients: local immunosuppression or islet toxicity? Transplantation $76: 1623-1625$ 
19. Ao Z, Matayoshi K, Lakey JR, Rajotte RV, Warnock GL (1993) Survival and function of purified islets in the omental pouch site of outbred dogs. Transplantation 56:524-529

20. Berman DM, O'Neil JJ, Coffey LC et al (2009) Long-term survival of nonhuman primate islets implanted in an omental pouch on a biodegradable scaffold. Am J Transplant 9:91-104

21. Gustavson S, Rajotte RV, Hunkeler D et al (2005) Islet autotransplantation into an omental or splenic site results in a normal beta cell but abnormal alpha cell response to mild non-insulininduced hypoglycemia. Am J Transplant 5:2368-2377

22. Hefty TR, Kuhr CS, Chong KT et al (2008) Omental roll-up: a technique for islet engraftment in a large animal model. J Surg Res. doi:10.1016/j.jss.2008.11.842

23. Kin T, Korbutt GS, Rajotte RV (2003) Survival and metabolic function of syngeneic rat islet grafts transplanted in the omental pouch. Am J Transplant 3:281-285

24. Yasunami Y, Lacy PE, Finke EH (1983) A new site for islet transplantation - a peritoneal-omental pouch. Transplantation $36: 181-182$

25. Pipeleers DG, Pipeleers-Marichal M, Hannaert JC et al (1991) Transplantation of purified islet cells in diabetic rats. I. Standardization of islet cell grafts. Diabetes 40:908-919

26. Ling Z, Pipeleers DG (1996) Prolonged exposure of human beta cells to elevated glucose levels results in sustained cellular activation leading to a loss of glucose regulation. J Clin Invest 98:2805-2812

27. Merino JF, Nacher V, Raurell M, Biarnés M, Soler J, Montanya E (2000) Optimal insulin treatment in syngeneic islet transplantation. Cell Transplant 9:11-18
28. Clark PM (1999) Assays for insulin, proinsulin(s) and C-peptide. Ann Clin Biochem 36:541-564

29. Mattsson G, Carlsson PO, Olausson K, Jansson L (2002) Histological markers for endothelial cells in endogenous and transplanted rodent pancreatic islets. Pancreatology 2:155162

30. Carlow DA, Gold MR, Ziltener HJ (2009) Lymphocytes in the peritoneum home to the omentum and are activated by resident dendritic cells. J Immunol 183:1155-1165

31. Korsgren O, Jansson L (1994) Porcine islet-like cell clusters cure diabetic nude rats when transplanted under the kidney capsule, but not when implanted into the liver or spleen. Cell Transplant 3:4954

32. Lin Y, Goebels J, Xia G, Ji P, Vandeputte M, Waer M (1998) Induction of specific transplantation tolerance across xenogeneic barriers in the T-independent immune compartment. Nat Med $4: 173-180$

33. Moberg L, Johansson H, Lukinius A et al (2002) Production of tissue factor by pancreatic islet cells as a trigger of detrimental thrombotic reactions in clinical islet transplantation. Lancet 360:2039-2045

34. Jansson L, Carlsson P-O (2002) Graft vascular function after transplantation of pancreatic islets. Diabetologia 45:749-763

35. Mattsson G, Jansson L, Carlsson P-O (2002) Decreased vascular density in mouse pancreatic islets after transplantation. Diabetes 51:1362-1366

36. Merani S, Toso C, Emamaullee J, Shapiro A (2008) Optimal implantation site for pancreatic islet transplantation. B J Surg 95:1449-1461 